\title{
Review \\ Nursery Culture of Mud Crab, Genus Scylla, a Review: The Current Progress and Future Directions
}

\author{
Muhammad Nur Syafaat ${ }^{1,2}$, Mohamad Nor Azra ${ }^{2}$, Khor Waiho ${ }^{2,3}$, Ambok Bolong Abol-Munafi ${ }^{2}$, Mohammad \\ Syahnon ${ }^{2}$, Ghazali Azmie'2, Hongyu Ma ${ }^{3,4}$ and Mhd Ikhwanuddin 2, $3^{*}$
}

Citation: Syafaat, M.N,; Waiho, K.; Azra, M.N.; Abol-Munafi, A.B.; Syahnon, M.; Azmie, G.; Ma, H.; Ikhwanuddin, M. Nursery culture of mud crab, genus Scylla, a review: The current progress and future directions. Animals 2021, 11, x. https://doi.org/10.3390/xxxxx

Academic Editor: First Last

Received:

Accepted:

Published:

Publisher's Note: MDPI stays neutral with regard to jurisdictional claims in published maps and institutional affiliations.

Copyright: (c) 2021 by the authors. Submitted for possible open access publication under the terms and conditions of the Creative Commons Attribution (CC BY) license (http://creativecommons.org/licenses /by/4.0/).
1 Research Institute for Brackishwater Aquaculture and Fisheries Extension, Maros 90512, Indonesia.

2 Higher Institution Centre of Excellence (HICoE), Institute of Tropical Aquaculture and Fisheries, Universiti Malaysia Terengganu, Kuala Nerus 21030, Malaysia.

3 STU-UMT Joint Shellfish Research Laboratory, Shantou University, Shantou 515063, China

4 Shantou University, Guangdong Provincial Key Laboratory of Marine Biotechnology, Shantou 515063, China.

* Correspondence: +6096683501; ikhwanuddin@umt.edu.my (M.N.S.; muhammad.nursyafaat@kkp.go.id) (M.N.A.: azramn@umt.edu.my) (K.W.; waiho@umt.edu.my) (A.B.A.: munafi@umt.edu.my) (M.S.: syahnon.m@umt.edu.my) (G.A.: azmie@umt.edu.my) (H.M.: mahy@stu.edu.cn)

Simple Summary: Increasing scarcity of limited culture techniques for future aquaculture candidates especially for portunid crab species is still unclear. Thus, nursery culture knowledge is important for successful commercial seed production, especially for the highly delicacy mud crab, genus Scylla. The aim of this review paper is to summarize the status and information on the current nursery culture stage of Scylla mud crab. Various aspects of mud crab hatchery that described in this paper are expected to make it easier for practitioners or lay people to understand mud crab nursery easily. This study is also expected to provide motivation to researchers in conducting research and development on mud crab nursery in the future so that the production of mud crab crablets from the hatcheries can be increased and profitable.

Abstract: This study attempted to explain the definition, objectives, and key stages in mud crab nursery activities. The nursery stages of Scylla spp was started from megalopa stage to several crablet instar stages or started from earlier crablet stage to several crablet stages. Direct stocking of megalopa into ponds is not recommended due to their sensitivity. Instead, nursery rearing is needed to produce mud crab of larger size before stocking. Individual nursery rearing results in higher survival rate (up to 100\%), but with reduced growth rate, and a more complicated maintenance process compared with communal rearing. Nursery of mud crab can be done indoors, or outdoors, with adequate shelter and feed required to obtain good survival and growth performance. Artemia nauplii are the main, established nursery feed, particularly at megalopa stage, while survival rate may be improved if combined with artificial feed, such as micro bound diet formulations. Water quality parameters, identical to those proposed in tiger shrimp culture, can followed. Crablets may be transported to the pond location with, or without water. The provision of monosex seeds from mud crab hatcheries is expected to become more common, increasing seed price, and thus improving income of farmers. Numerous aspects of mud crab nursery, including nutrition, feeding strategies, understanding of their behaviour, i.e., cannibalism, control of environmental factors, and practical rearing techniques, still need further improvement.

Keywords: aquaculture; shellfish; future food; nursery stage; mud crab; juvenile; seed production; hatchery; crablet; breeding

\section{Introduction}

Mud crab is one of the favorite seafood products both local and international markets $[1,2]$. The demand for this species increases annually [3], which has led to overfishing, as most mud crab landings still rely heavily on captured fisheries [4,5]. The impact on wild populations could be lessened, if sufficient support were received from the aquaculture 
sector in the form of seed supply from hatcheries [2,6,7]. As well, mud crab grow-out and fattening activities incorporated within the mangrove area, known as silvo-fishery techniques $[8,9,10]$, culture in earthen ponds [11,12] or in concrete ponds [13], and grow-out activity in indoor conditions [14,15], could all contribute to hatchery replacement of wild catch. However, mud crab hatchery activities continue to be constrained by low survival rates, hence the supply of seeds is still very limited for large-scale aquaculture purposes $[2,16]$. Disease control and improved nutritional condition of larvae in seed production tanks also need to be developed, for reliable mass seed production of portunid crabs to be implemented [17].

Mud crab hatcheries typically involve maintenance of larvae to crablet size ( $>5 \mathrm{~mm})$ before marketing to farmers [18,19]. Maintenance of mud crab larvae in the hatchery has three stages, namely the Zoea 1 (Z1) to Zoea 5 (Z5) larvae, Z5 to Megalopa (M), and the maintenance of $M$ to crablet phase [20]. The hatchery production process of mud crab crablet takes about 30 days (starting from Z1 to Crablet 2-3 (C2-C3)) [21]. The crablet production period for mud crabs is longer than that of blue swimming crab, Portunus pelagicus. This is because the zoea mud crab phase consists of 5 phases, being more than undergone for $P$. pelagicus, and the duration for each phase of the zoea is longer (3-4 days) compared to $P$. pelagicus (2-3 days) [22].

Unlike $P$. pelagicus, where high survival has been observed when stocking into ponds at the megalopae phase, the critical transition step of megalopa to Crablet 1 (C1) in mud crabs has typically produced inconsistent and unreliable results, with high mortality often reported during metamorphosis from megalopa to C1 stage $[23,24]$. Therefore, the nursery phase of mud crab (from megalopae to early crablet stages $(\geq C 3)$ ) needs to be improved to a large number of high qualities crablets $[17,25,26]$. The larval rearing process was thoroughly reviewed by Waiho et al. [2], while the current review is focused on rearing techniques, and parameters involved in the nursery phase of mud crab, genus Scylla, including principal technical practices of mud crab nursery, from stocking to transportation, and some issues during this phase are identified and potential solutions discussed.

\section{Mud Crab Culture Nursery Stages}

The nursery stages of mud crab, genus Scylla, include one megalopa stage, and subsequent crab instar stages. The transition from megalopa (M) into the $C 1$ stage is around 6-7 days [24]. Maintenance of megalopa stage to the $1^{\text {st }}$ crablet instar (Crablet 1 stage (C1)) is one of the most critical periods of mud crab larvae rearing. Among the assumed bottle necks of this phase are; (i) nutritional factors that trigger the occurrence of Moulting Death Syndrome (MDS) [27], and (ii) high cannibalism level, since $\mathrm{M}$ is the first stage when pincers appear $[28,29,30]$. Maintenance of $\mathrm{M}$ to $\mathrm{C} 1$ of mud crabs requires more serious attention because the survival rate remains very low $(<50 \%)$ and is inconsistent. Studies related to nutritional, environmental, and behavioural aspects at this phase are needed to optimize seed production from hatcheries. Aside from megalopa to the crablet phase, extended nursery stage of mud crabs is done to produce larger size of young crabs [29,31,32]. 


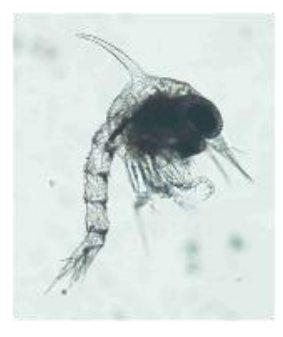

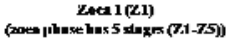

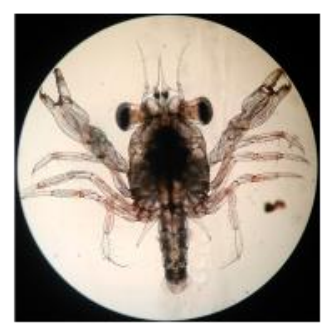

Megavopaphase

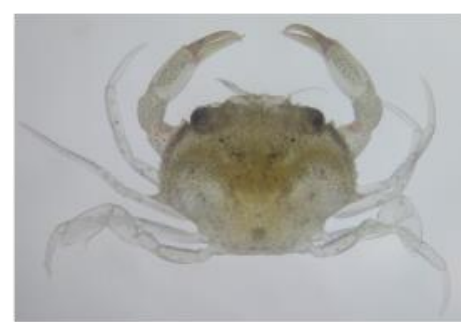

Crabsec (c3)

Figure 1. Larvae development of mud crab from Zoea to Crablet stages

\section{Mud Crab Nursery Techniques}

\subsection{Nursery Area}

Nursery area may be located indoors or outdoors. Nursery area may be located indoors or outdoors. $\mathrm{M}$ are nursed in concrete tanks, fiberglass or plastic tanks, or net cages within brackishwater ponds (Table 1 ) $[24,25,28,32,33]$. The nursery of mud crabs in indoor conditions allows for easier control of various parameters, e.g., water quality control, water exchange, siphoning of waste and excess feed, as well as improving access for daily observation of crablets. However, the production and growth of crablets in net cages, or in ponds, has shown better results [33]. Natural lighting, accompanied by the presence of natural food in ponds, are believed to be the trigger factors for the growth of crablets maintained in net cages.

The nursery of mud crabs in indoor conditions will still need to be further investigated, to optimize production of crablets from hatcheries. Among the methods that can be applied to indoor mud crab protocols is biofloc technology. Research will need to determine if biofloc water from shrimp farming industry waste may be used as an alternative medium for future $\mathrm{M}$ maintenance, and whether feed, in the form of biofloc flour, can be an alternative feed for $\mathrm{M}$ and crablet.

\subsection{Rearing Techniques}

Another important consideration is whether to rear individually, or communally. Nursery rearing of $\mathrm{M}$ individually, in good water quality condition, could raise survival up to $90-100 \%$ [26,34]. Although a high survival rate is valuable, extra effort is required to implement the individual crablet rearing technique, especially during feeding. Automatic feed machines during individual $\mathrm{M}$ rearing could be developed to have low capital and operating costs, to reduce high manpower cost and inefficiency of manual feeding.

In the communal rearing technique, canibalism is a major problem. To reduce cannibalism, black nylon, bunched netting, or seaweed may be placed at the bottom of rearing tanks, as shelters, while some may also be allowed to float in the water column $[24,32,35,36]$. During crablet or juvenile stages, shelter options include plastic strings, bamboo tubes, and open sand substratum [35], or brick and shell shelters [29]. The presence of shelters and the availability of sufficient feed greatly reduce the rate of cannibalism [37], which is reasonable, since decapod larvae usually associate with floating leaves and clumps of algae in natural conditions, and this behaviour could reduce predation, save energy when close to the turbid water surface, or function as a transport mechanism [38]. Some studies related to the nursery of mud crab started at megalopa and crablet stages is presented in Table 1. 


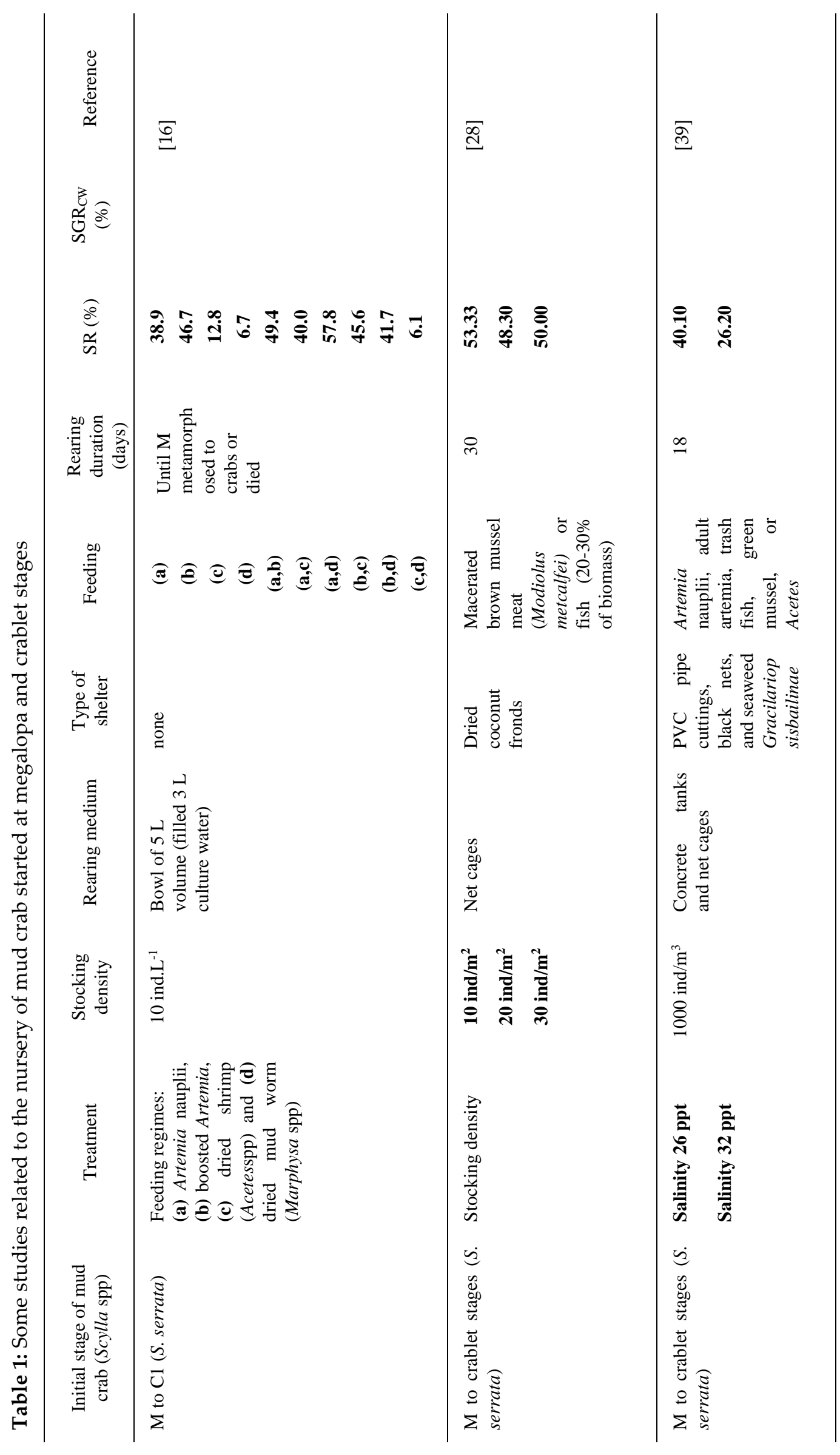




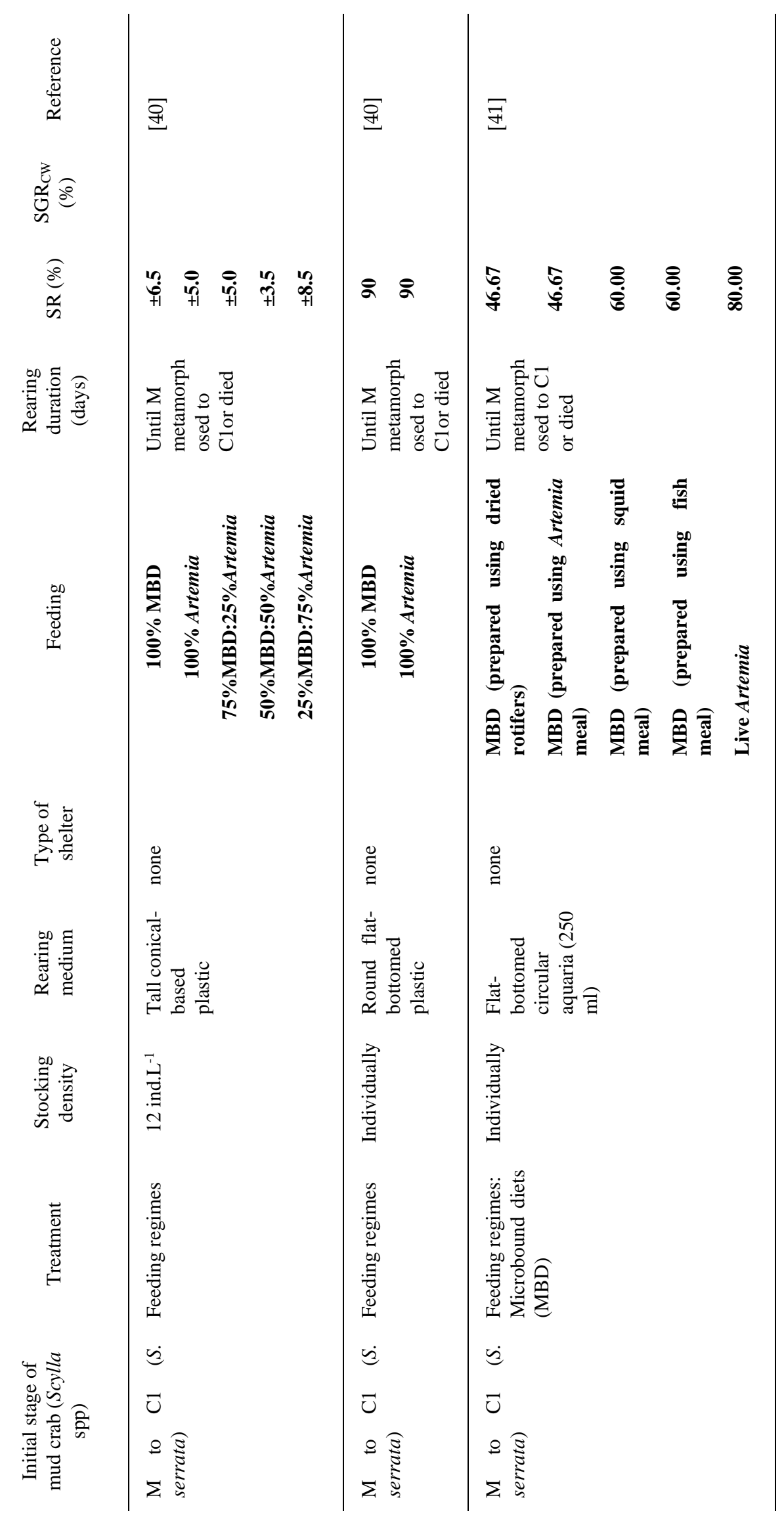




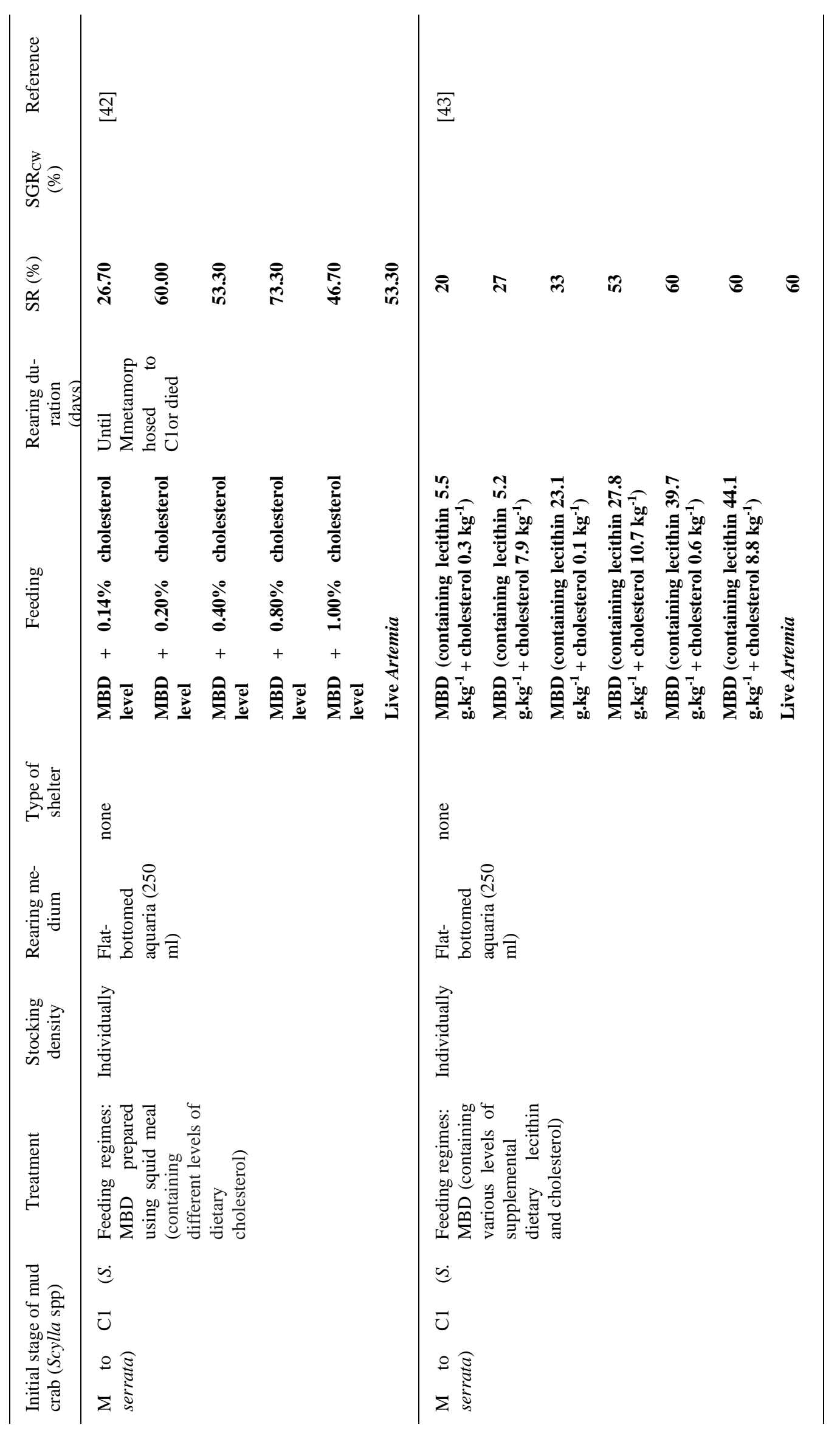




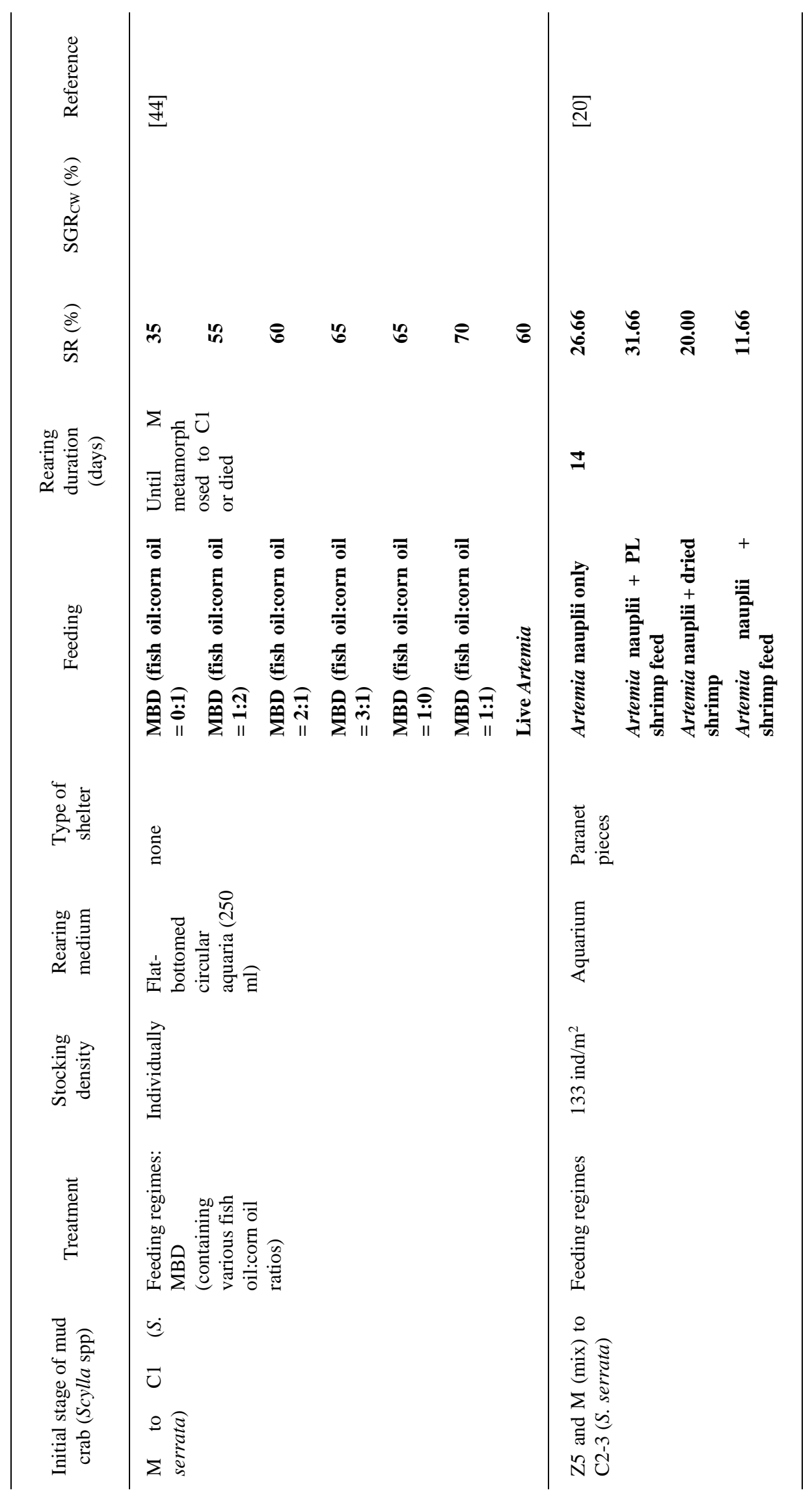




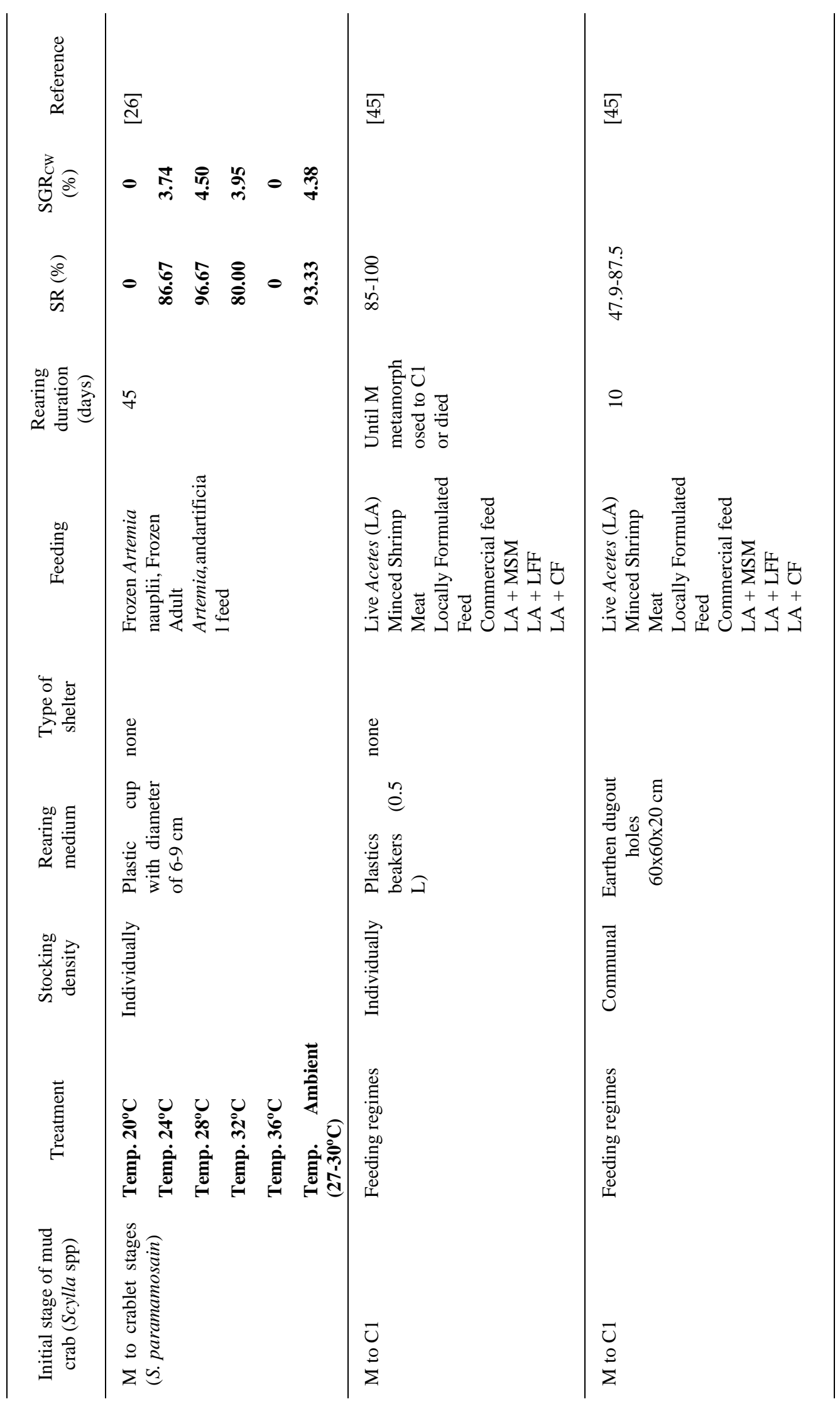




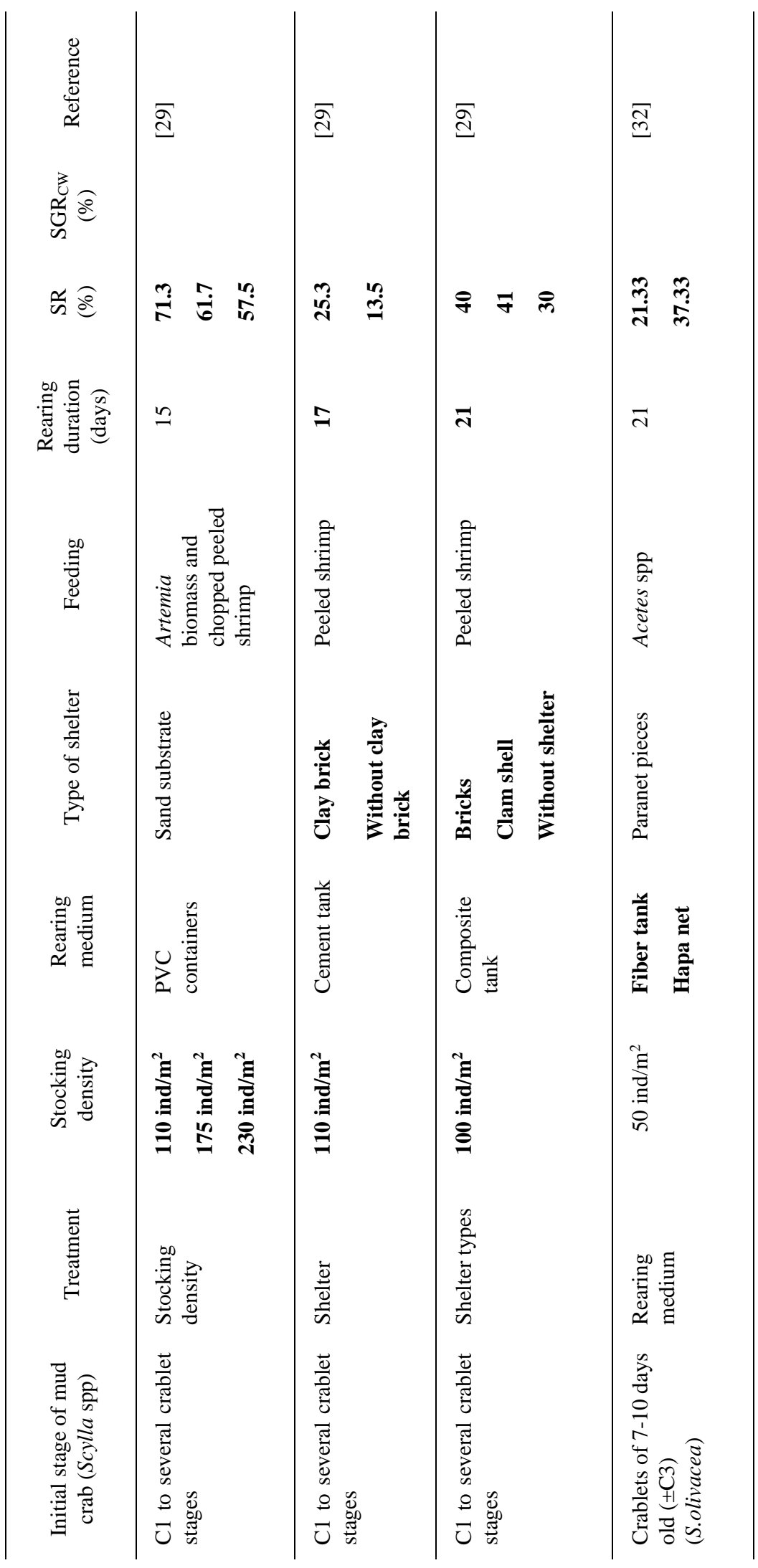




\subsection{Seed Stocking}

\subsubsection{Stocking Strategies}

The stocking density of 3-5 days-old $\mathrm{M}$ in nursery tanks is typically around 2,000$4,000 / \mathrm{m}^{3}$ (1000-2000/ton) of water [24,25]. Based on the habit of megalopa stage crablets to go down to the bottom just before moulting to $\mathrm{C} 1$, the recommended stocking technique for $M$ is based on area (ind $/ \mathrm{m}^{2}$ ). Further study related to the optimal density of $\mathrm{M}$ per unit area needs to be carried out in future. Stocking of $M$ with densities of $10,20,30 \mathrm{ind} / \mathrm{m}^{2}$ in net cages within earthen ponds was shown to attain an average 50.5\% survival rate [28], while rearing of $\mathrm{M}$ in an aquarium with a density of $133 \mathrm{ind} / \mathrm{m}^{2}$ had a survival rate between 11.7-31.7\%, although on different feeds [20]. Besides stocking density, another factor that needs to be considered, to determine stocking density of $\mathrm{M}$, is optimal water depth that can be used during the maintenance process.

When C1 was cultured at high densities of 110, 175, and $230 \mathrm{crabs} / \mathrm{m}^{2}$ for 15 days, survival rates of $71 \%, 62 \%$ and $58 \%$ were reported, respectively [29]. Longer nursery period of 30 days with lower density of $70 \mathrm{ind} / \mathrm{m}^{2}$ had a survival rate of $52-66 \%$, while further extended nursery to 60 days with a density of $30 \mathrm{ind} / \mathrm{m}^{2}$ attained a survival rate of $64-67 \%$ [29]. A lower survival rate of between 21 and 37\% was found by Syafaat et al. [32], for mud crab crablet (Day 7-10) reared for 21 days at a density of $50 \mathrm{ind} / \mathrm{m}^{2}$. Hence, further research is needed to identify the factors controlling survival rate, in relation to stocking density.

\subsubsection{Age of Megalopa}

The age of $\mathrm{M}$ at moulting is likely to affect moulting success of $\mathrm{M}$ to $\mathrm{C1}$. Syafaat [26] reported a lower survival rate of 2-3 day megalopa, than for 5-6 day during their molt from $\mathrm{M}$ to $\mathrm{C} 1$ (reared individually). In communal culture condition, using hapa nets within earthen pond of $80 \mathrm{~cm}$ water depth, older M (3 and 4-day) showed better survival than Z5, 1-day old, and 2-day old M [46]. A side from cannibalism and other factors, such as environmental conditions, feed nutrition, and disease, age of $\mathrm{M}$ at stocking is another factor that needs to be considered in order to maximize survival from $M$ to $C 1$, particularly under an individual culture condition.

\subsubsection{Transportation of Megalopa}

During transportation, avoidance of a stationary transport condition, or continuous agitation, has been indicated to reduce the probability of $\mathrm{M}$ to grasp each other ([47]. Transportation of $\mathrm{M}$ is typically in plastic bags with density of 200-300 ind/L [28]. Survival rate is usually lower at higher density. For example, Quinito and Parado-Estepa [47] reported that survival of $\mathrm{M}$ over a 6-h simulated transport (including shaking) could reach $99.3 \pm 1.6 \%, 93.0 \pm 5 \%$, and $94.0 \pm 3.8 \%$ for densities of 50,100 and 150 ind/L, respectively, leading to a conclusion that lower density, i.e., 50 ind/L, is preferable. Besides density, temperature also affects survival rate of $\mathrm{M}$ during transportation. Survival during transport of $\mathrm{M}$ at a temperature of $28^{\circ} \mathrm{C}$ was lower than at a temperature of $24^{\circ} \mathrm{C}$ [47].

\subsection{Feeding Strategies}

Artemia is often used as the main feed during the maintenance of $\mathrm{M}$ to crablet stages, with additional dried shrimp, dried mud worms, prawn/shrimp meat, fish meat, or artificial feed (shrimp larvae feed) being added as high as 1-5 mg/L concentration (Table 2) $[16,20,48,49]$. Chen et al. [50] clarified that $M$ were able to capture prey whose sizes ranged from nauplii up to small adult Artemia. Apart from suitable feed size, feed nutritional quality is another important component supporting development of $\mathrm{M}$ into $\mathrm{C} 1$ stage. The use of enriched Artemia (instar 2) resulted in better survival than use of only Artemia nauplii [16]. Acetes is a potential live food in mud crab nursery from megalopa to crablet stage. The rearing of megalopa on Acetes alone, or combined with minced shrimp meat, locally formulated feed, or commercial feed, showed better survival than treatments fed with 
minced shrimp meat, locally formulated feed, or commercial feed alone [45]. It is recommended to start artificial feed supplementation at the $\mathrm{M}$ stage, as diet modulation of gut evacuation time (GET) is expected to begin at this stage [51], while digestive enzyme activity of mud crab larvae tends to increase with increasing larval stage $[52,53]$.

Supplementation with artificial feed (shrimp post larvae feed), and Artemia, showed higher survival rate when compared to treatment being fed Artemia alone, in rearing from the $\mathrm{Z} 5$ and $\mathrm{M}$ stages [20,49]. The use of juiced artificial feed, with added spirulina powder and digezym (containing amylase, protease, lactase, and selulose), together with Artemia nauplii, produced more $\mathrm{C} 1$ than treatment being fed only artificial feed juice (without spirulina powder and digezym), and Artemia nauplii [54]. Shorter moulting intervals shown in M fed only with Microbound Diet (MBD), or MBD combined with Artemia, suggested that MBD may contain beneficial nutrients not provided by Artemia [40], which have been evaluated as Eicosapentaenoic acid (EPA) and Docosahexaenoic Acid (DHA) $[16,55,56]$ and as lipid profile [44].

The low content of both EPA and DHA in rotifers and Artemia could affect the vitality of larvae $[53,57,58]$. Inappropriate lipid profile for marine crustaceans, found in rotifer and Artemia nauplii, could affect both larval development and survival of mud crab larvae [44]. MBD feed, containing squid meal with proper cholesterol and lechitin levels, provides the equivalent survival of megalopa and can even be better than diet of only live Artemia $[41,42,43]$. Further, MBD feed containing a fish oil to corn oil ratio of as high as 1:1 showed a better survival of $\mathrm{M}$, compared to treatment that was fed only Artemia nauplii [44].

As soon as $\mathrm{M}$ metamorphose to crab stage, they are fed with minced trash fish, green mussel, Acetes [39], fresh chopped shrimp or tilapia [29], brown mussel [59], frozen adult Artemia [26], or artificial feed [20,21].

Table 2: Feeding strategies at megalopa and crablet stages of mud crab

\begin{tabular}{|c|c|c|c|c|}
\hline \multirow{2}{*}{$\begin{array}{l}\text { Mud crab } \\
\text { stages }\end{array}$} & \multicolumn{2}{|c|}{ Type and dosage of feed } & \multirow{2}{*}{$\begin{array}{c}\text { Feeding } \\
\text { Frequency } \\
\text { (times/day) }\end{array}$} & \multirow[t]{2}{*}{ Reference } \\
\hline & Artemia nauplii & Additional feed & & \\
\hline $\begin{array}{l}\text { Megalopa } \\
\text { to crablet } \\
\text { instar }(\mathrm{C} 1)\end{array}$ & 5-30 ind. $\mathrm{ml}^{-1}$ & $\begin{array}{l}\text { Macerated prawn ab- } \\
\text { domen }\end{array}$ & 1 & [48] \\
\hline $\begin{array}{l}\text { Megalopa } \\
\text { to crablet }\end{array}$ & $\begin{array}{c}0.75 \text { ind.ml }^{-1} \\
\text { (Artemia nauplii) } \\
0.5 \text { ind.ml }^{-1} \\
\text { (boosted Artemia) }\end{array}$ & $\begin{array}{c}\text { Dried shrimp (Acetes } \\
\text { spp) and dried mud } \\
\text { worm (Marphysa spp) } \\
(5 \mathrm{mg} / \mathrm{L})\end{array}$ & N/A & [16] \\
\hline $\begin{array}{l}\text { Megalopa } \\
\text { to crablets }\end{array}$ & $3-5$ ind. $\mathrm{ml}^{-1}$ & $\begin{array}{l}\text { Trash fish, green mus- } \\
\text { sel or Acetes spp } \\
\text { (given when mega- } \\
\text { lopa metamorphosed } \\
\text { to crab stage) }\end{array}$ & 2 & [39] \\
\hline $\begin{array}{l}\text { Megalopa } \\
\text { to crablets }\end{array}$ & N/A & $\begin{array}{l}\text { Macerated brown } \\
\text { mussel meat (Modiolus } \\
\text { metcalfei) or fish (20- } \\
30 \% \text { of biomass) }\end{array}$ & 3 & [28] \\
\hline $\begin{array}{l}\text { Megalopa } \\
\text { to crablet } \\
\text { instar }\end{array}$ & N/A & $\begin{array}{l}\text { MBD (with different } \\
\text { formulations) }\end{array}$ & 2 & {$[40,41,42,43,44]$} \\
\hline $\begin{array}{l}\text { Zoea } 2 \text { to } \\
\text { crablet } 1\end{array}$ & $\begin{array}{c}4 \times 5 \mathrm{~g} / \operatorname{tank}\left(1 \mathrm{~m}^{3}\right) \\
/ \text { day }\end{array}$ & $\begin{array}{l}\text { Artificial feed juice (3 } \\
\times 5 \mathrm{~g} / \operatorname{tank}\left(1 \mathrm{~m}^{3}\right) / \text { day) }\end{array}$ & $3-4$ & [54] \\
\hline
\end{tabular}




\begin{tabular}{lcccc}
\hline $\begin{array}{c}\text { Zoea } 5 \\
\text { and Mega- } \\
\text { lopa to } \\
\text { crablets }\end{array}$ & N/A & Shrimp larvae feed & [49] \\
$\begin{array}{l}\text { Megalopa } \\
\text { to crablets }\end{array}$ & $\begin{array}{c}3-5 \text { ind.ml }{ }^{-1}(\mathrm{en}- \\
\text { riched Artemia } \\
\text { nauplii) }\end{array}$ & $\begin{array}{c}\text { Shrimp meat and } \\
\text { shrimp larvae feed }\end{array}$ & 2 & [21] \\
${ }^{* N}$ /A: Not available &
\end{tabular}

\section{Water Quality}

Water quality conditions tolerable in both larval rearing, and brood stock maintenance of mud crab include 28-35 ppt salinity (10-35 ppt for nursery and grow out), temperature of $27-32^{\circ} \mathrm{C}, \mathrm{pH}$ of $7.5-8.5, \mathrm{DO}>4 \mathrm{ppm}$, and ammonia $<0.01 \mathrm{ppm}$ [60]. Alkalinity $>80 \mathrm{ppm}$ has been suggested for mud crab farming (ideally $120 \mathrm{ppm}$ ) [61]. As the optimal water parameters for mud crab farming are still considered to be under development, optimal water parameters for tiger prawns may be used as guidance (Table 3) [61].

Temperature and salinity are the two main parameters to be considered routinely both in larvae rearing, and nursery phases of mud crab $[26,31,34,62,63,64,65]$. These two parameters greatly affect physiological processes, having an impact on the growth of portunid crab $[22,66,67]$. The recommended salinity for the rearing of $\mathrm{M}$ and $\mathrm{C} 1$ is between $20-25$ ppt $[31,34,62,63,64,65]$, while recommended temperature is $28-30^{\circ} \mathrm{C}[26,31,66]$. The optimal temperature recommended for the moulting process of $\mathrm{M}$ to $\mathrm{C} 1$ is $28^{\circ} \mathrm{C}$, with a lower temperature condition between 24 and $28^{\circ} \mathrm{C}$ having been shown to be more conducive to the moulting process of $\mathrm{M}$ to $\mathrm{C} 1$, much preferred to high temperature (i.e., up to $32^{\circ} \mathrm{C}$ ), or fluctuating temperature conditions [26].

The use of artificial feed during mud crab larvae rearing may trigger the growth of Vibrio spp. on culture media [21]. Hence, the use of antibiotics (which are only allowed according to the rules of individual countries) to control the growth of Vibrio spp. is still needed. However, the rearing of portunid crab larvae with probiotics has been proven to improve production of mud crab crablet [26], and is able to suppress and control the development of pathogenic of Vibrio spp. populations [3,68], where by their use is recommended over the use of antibiotics.

Table 3: Water quality parameters that suggested for mud crab culture operation

\begin{tabular}{|c|c|c|}
\hline Parameters & Optimum range / value & Sampling frequency \\
\hline Dissolved oxygen (DO) & $\begin{array}{l}>5 \mathrm{ppm}^{*} \text { (mud crab is tolerant } \\
\text { in low oxygen level) }\end{array}$ & Twice a day \\
\hline $\mathrm{pH}$ & $\begin{array}{l}7.5-9 ;<0.5 \text { daily variation } \\
\text { with } 7.8 \text { is optimum value }\end{array}$ & Twice a day \\
\hline Temperature & $25-35^{\circ} \mathrm{C}($ Max and Min $)$ & Weekly \\
\hline Salinity & $10-25$ ppt for crablet & Weekly \\
\hline Total ammonia nitrogen (TAN) & $\begin{array}{c}<3 \mathrm{ppm}^{*} \text { (crablet has tolerance } \\
\text { to high ammonia) }\end{array}$ & Daily observation is needed \\
\hline Un-ionized ammonia $\left(\mathrm{NH}_{3}\right)$ & $\begin{array}{c}<0.25 \mathrm{ppm}^{*} \text { (crablet has toler- } \\
\text { ance to high ammonia) }\end{array}$ & Daily observation is needed \\
\hline Nirite $\left(\mathrm{NO}_{2}\right)$ & $\begin{array}{l}<10 \mathrm{ppm} \text { at salinity }>15 \mathrm{ppt} \\
<5 \mathrm{ppm} \text { at salinity }<15 \mathrm{ppt}\end{array}$ & Daily observation is needed \\
\hline Alkalinity & $>80$ ppm (ideally 120 ppm) & Daily observation is needed \\
\hline Hardness & $>2000$ ppm $^{*}$ & Daily observation is needed \\
\hline Hidrogen sulfida & $<0.1 \mathrm{ppm}^{*}$ & Weekly \\
\hline Turbidity & $20-30 \mathrm{~cm}^{*}$ & Daily \\
\hline
\end{tabular}

*Range for Penaeus monodon (used to provide information for farmers)

Source: [61] 


\section{Harvest and Transportation of Crablet}

The harvesting process for the nursery phase ( $\mathrm{M}$ to crablets, or from early crablets (C1-C2) to larger crablets phase) occurs between 2 and 4 weeks after stocking. Long nursery periods in small areas (high density, with minimal shelter), will lead to high mortality due to cannibalism. Two methods, the dry (moist) method [19,69], and the wet method (with water) [70] can be used to deliver harvested crablets to grow-out farms (Table 3). The dry method of transportation, without water, uses materials that function as shelter within containers. The wet method provides water, typically in a plastic bag, and supplied with sufficient oxygen above the water. Shelter is also a requirement of wet method transportation, i.e., nylon net.

Table 3: Literature related to transportation of mud crab crablet

\begin{tabular}{|c|c|c|c|}
\hline $\begin{array}{l}\text { Life stage of mud } \\
\text { crab (days / sizes) }\end{array}$ & $\begin{array}{c}\text { Crablet (D20) } \\
\text { Scylla paramamosain }\end{array}$ & $\begin{array}{l}\text { Crablet (with width car- } \\
\text { apace less than } 1 \mathrm{~cm} \text { ) } \\
\text { Scylla paramamosain }\end{array}$ & $\begin{array}{c}\text { Crablet (D37) } \\
\text { Scylla tranquebarica }\end{array}$ \\
\hline Methods & Wet & Dry (without water) & Wet \\
\hline Medium & $\begin{array}{l}\text { Plastic bags (filled } \\
\text { with oxygen) }\end{array}$ & $\begin{array}{c}\text { Plastic bags (filled with } \\
\text { oxygen) }\end{array}$ & $\begin{array}{l}\text { Styrofoam box } \\
\qquad(40 \times 50 \mathrm{~cm})\end{array}$ \\
\hline Density & $50,100,150$ ind/pack & $200 \& 300$ crablet & $700 \mathrm{ind} / \mathrm{box}$ \\
\hline Shelter & $\begin{array}{l}\text { A nylon net }(20 \times 40 \\
\qquad \mathrm{cm})\end{array}$ & $\begin{array}{l}\text { Wet cloth along with } \\
\text { seaweed (Gracillaria } \\
\text { spp.) }\end{array}$ & Paranet \\
\hline Duration (hour) & 5 & 5 & 6 \\
\hline Survival rate (\%) & $88-97$ & $98-99$ & $>95$ \\
\hline Reference & [70] & [69] & [19] \\
\hline
\end{tabular}

\section{Sex Differentiation in Crablet Stage}

Morphological sex differentiation of mud crab is based on the shape of the abdominal flap in the earlier crablet stages, i.e., for S. paramamosain, and can be seen clearly at C5 stage (CW of $\pm 1 \mathrm{~cm}$ ) using a microscope (magnification of 8-20x), whereas the difference can be seen with the naked eye in the $\pm \mathrm{C} 9$ stage $(\mathrm{CW}$ of $\pm 2 \mathrm{~cm})$ [26]. In mud crab, S. serrata, the different shape of the male and female abdomen enables sexing of crabs above $3 \mathrm{~cm}$ carapace width with casual inspection, while below this size sex can be determined at 30x by means of a binocular microscope [71]. Females are recognized by the presence of 4 pairs of biramous pleopods, and oviduct depression on the sternites of the 6th thoracic segment, while males are recognized by the presence of copulatory pleopods, and the absence of oviduct depressions [71].

The ability to distinguish the sex of mud crabs in the crablet phase can be an added value for mud crab hatcheries, allowing sale at a higher price. In mud crab culture, monosex culture is highly profitable as mud crab shows obvious sexual dimorphism. Monosex culture of all male shows higher Specific Growth Rates (SGRs) compared to all female [9], and culture trial of mono-sex culture (all male and all female) has yielded significantly higher production and survival compared to the mixed culture [72]. Therefore, availability of monosex seeds is also important to support monosex mud crab farming in 
brackishwater ponds. Further study on sex reversal technology for mud crab to produce mono sex crab seeds is important to conduct in the future.

\section{Conclusion and Recommendations}

Mud crab nursery in the hatchery, beginning from the M stage, is important to production because the stocking of $\mathrm{M}$ directly to ponds has not shown good results, when compared with species such as $P$. pelagicus. Although operating mud crab nursery for crablets individually exhibits higher survival, when compared to communal rearing, the individual nursery involves higher complexity, and resourcing, so that it will be necessary to consider rearing technology using automatic machinery, especially for the feeding process. Mud crab nursery can be carried out both indoors (using plastic, fiberglass, or concrete tanks), and outdoors (earth, lined, or concrete ponds) within net cages. In all applications, rearing needs to be accompanied by the use of adequate shelter, particularly for communal nursery.

Availability of adequate food is one of the main things to be considered to suppress cannibalism. Feed in the form of live Artemia is still the most common, main feed in the M phase, but Artemia combined with additional feed (artificial feed, worn meal, shrimp meat) provides better survival compared to Artemia alone. MBD of the right composition is a feed candidate to replace or substitute for Artemia in the M phase.

Although mud crabs are believed to show good resilience in nature, and survive in extreme conditions (e.g., in mud, and without water), water quality parameters for shrimp culture can be used as a guide in mud crab farming activities. Studies related to the transportation of crablet still need to be carried out to produce practical, inexpensive methods, and to determine the extent of crablet resistance during transportation without water. In addition, improved knowledge of sex differentiation of mud crab during early crablet stage would be expected to provide added value to mud crabs hatcheries.

Various aspects of mud crab hatchery that are described in this paper are expected to make it easier for practitioners to understand mud crab nursery operations. This study is also expected to provide motivation to researchers in conducting research and development on mud crab nursery in the future, so that the total production of mud crab crablets from hatcheries can be increased, and also become more profitable.

Supplementary Materials: No supplementary available for the review paper, all information have been added to the summarized table.

Author Contributions: Conceptualization, M.N.S.; resources, M.N.S., M.I. and A.B.A.; writingoriginal draft preparation, M.N.S; writing - review and editing, M.N.S; M.I., K.W. and M.N.A.; visualization, M.N.S.; supervision, M.I.; project administration, M.N.A., M.S., A.G.; funding acquisition, M.I. and H.M. All authors have read and agreed to the published version of the manuscript.

Funding: This study was supported by the Ministry of Higher Education, Malaysia under the Higher Institutional Centre of Excellence (HICoE), awarded to the institute in the early January 2021.

Acknowledgments: The researchers are pleased to Institute of Tropical Aquaculture and Fisheries, Universiti Malaysia Terengganu for direct or indirect contribution to this review paper.

Conflicts of Interest: The authors declare no conflict of interest. The funders had no role in the design of the study; in the collection, analyses, or interpretation of data; in the writing of the manuscript, or in the decision to publish the results.

\section{References}

1. Sathiadhas, R.; Najmudeen, T.M. Economic evaluation of mud crab farming under different production systems in India. Aquacult. Econ. Manag. 2004, 8(1/2), 99-110.

2. Waiho, K.; Fazhan, H.; Quinito, E.T.; Baylon, J.C.; Fujaya, Y.; Azmie, G.; Wu, Q.; Shi, X.; Ikhwanuddin, M.; Ma, H. Larval rearing of mud crab (Scylla): what lies ahead (Review). Aquaculture 2018, 493, 37-50. https://doi.org/10.1016/j.aquaculture.2018.04.047 
3. Gunarto.; Syafaat, M.N.; Herlinah.; Parenrengi, A.; Mustafa, A. Biological aspects and seed production technique of mud crabs Scylla spp. Amafrad Press. Jakarta., 2016. In Indonesian

4. Fazhan, H.; Waiho, K.; Norfaizza, W.I.W; Megat, F.H.; Ikhwanuddin, M. Inter-species mating among mud crab genus Scylla in captivity. Aquaculture 2017, 471, 49-54.

5. Fazhan, H.; Waiho, K.; Wee, H.B.; Surzanne, M.A.; Ma, H.; Ikhwanuddin, M. Predicting the sacculinid Sacculina beauforti infection status of the orange mud crab Scylla olivacea by discriminant analysis. Aquaculture 2018, 491, 128-134.

6. Ikhwanuddin, M.; Lan, S.S.; Abdul Hamid, N.; Fatiha, Z.S.N.; Azra, M.N.; Siti Aisah, A.; Abol-Munafi, A.B. The embryonic development of orange mud crab, Scylla olivacea (Herbst, 1796) held in captivity. Iran. J. Fish. Sci. 2015, 14(4), 885-895. http://jifro.ir/browse.php?a id=1115\&sid=1\&slc lang=en

7. Ikhwanuddin, M.; Azmie, G.; Nahar, S.F.; Wee, W.; Azra, M.N.; Abol-Munafi, A.B. Testis maturation stages of mud crab (Scylla olivacea) broodstock on different diets. Sains Malays. 2018, 47(3), 427-432. http://dx.doi.org/10.17576/jsm-2018-4703-01

8. Triño, A. T.; Rodriguez, E. M. Mud crab (Scylla serrata) culture in tidal flats with existing mangroves. In J. H. Primavera, L. M. B. Garcia, M. T. Castaños, \& M. B. Surtida (Eds.), Mangrove-Friendly Aquaculture: Proceedings of the Workshop on Mangrove Friendly Aquaculture organized by the SEAFDEC Aquaculture Department, January 11-15, 1999, Iloilo City, Philippines, 2000, pp. 171-176.

9. Khatun, Mst. M.; Kamal, D.; Ikejima, K.; Yi, Y. Comparisons of growth and economic performance among monosex and mixedsex culture of red mud crab (Scylla olivacea Herbst, 1796) in bamboo pens in the tidal flats of mangrove forests, Bangladesh. Aquac. Res. 2009, 40, 473-485.

10. Widodo, A.F.; Sulaeman.; Jompa, H. Grow out of mud crab, Scylla serrata in mangrove area using silvo-fishery system. Proceeding of Seminar Nasional Limnologi V, 2010, pp. 750-759. In Indonesian.

11. Pillai, S.L.; Rajapackiam, S.; Sunderarajan, D. Mud crab Scylla tranquebarica culture in earthen pond at Tuticorin. Mar. biol. Ass. India. 2002, 44(1\&2), 245-248.

12. Syafaat, M. N.; Gunarto. The grow-out cultures of hatchery-produced mud crab Scylla tranquebarica (fabricius, 1798) cultured at different pond locations. Media Akuakultur 2018, 13(1), 21-30. In Indonesian. http://dx.doi.org/10.15578/ma.13.1.2018.21-30

13. Herlinah.; Sulaeman.; Widodo, A.F.; Gunarto. Application of box system as effort to increase of mud crab (Scylla serrata) grow out production in concrete pond. Proceeding of Seminar Nasional Tahunan VIII Hasil Penelitian Perikanan dan Kelautan, Gajah Mada University, 2011. RA-11 (8 pp). In Indonesian.

14. Syafaat, M.N.; Gunarto.; Sahabuddin. Water quality condition of mud crab, Scylla paramamosain culture using recirculating aquaculture system at different stocking density. Proceeding of Forum Inovasi Teknologi Akuakultur 2015, pp. 781-788. http://ejournalbalitbang.kkp.go.id/index.php/fita/article/view/1867

15. Islam, M.L.; Siddiky, M.N.M.; Yahya, K. Age and size at sexual maturity of same age group of male green mud crab (Scylla paramamosain). J. Entomol. Zool. 2018, 6(5), 366-371.

16. Williams, G.R.; Wood, J.; Dalliston, B.; Shelley, C.C.; Kuo, C.M. Mud crab (Scylla serrata) megalopa larvae exhibit high survival rates on Artemia-based diets. In Keenan, C.P., Blackshaw, A., (Eds.), Mud Crab Aquaculture and Biology, ACIAR Proceeding 1999, 131-140. https://www.aciar.gov.aulfile/68781/download?token=Nhup YsCY

17. Hamasaki, K.; Obata, Y.; Dan, S.; Kitada, S. A review of seed production and stock enhancement for commercially important portunid crabs in Japan. Aquac. Int. 2011, 19, 217-235.

18. Kulasekarapandian, S.; Panigrahi, A. Biology and fishery of mud crabs. In Anonim. Training manual on Mud crab breeding and culture. Central Institute of Brackishwater Aquaculture. Chennai, India, 2009, pp. 1-9.

19. Syafaat, M. N.; Gunarto. The grow-out cultures of hatchery-produced mud crab Scylla tranquebarica (fabricius, 1798) cultured at different pond locations. Media Akuakultur 2018, 13(1), 21-30. In Indonesian.

20. Syafaat, M.N.; Gunarto.; Usman. Rearing of mud crab (Scylla serrata) megalopa to crablet stages with different additional feed types. Proceeding of Forum Inovasi Teknologi Akuakultur 2016, pp.209-214. In Indonesian. http://ejournal-balitbang.kkp.go.id/index.php/fita/article/view/1746

21. Syafaat, M.N.; Gunarto.; Sulaeman.; Herlinah.; Ma, H.; Ikhwanuddin, M. Effects of different feeding regimes on larvae and crablets of purple mud crab, Scylla tranquebarica (fabricius,1798). Aquac. Rep. 2019, 15, 10231 https://doi.org/10.1016/j.aqrep.2019.100231

22. Azra, M.N.; Ikhwanuddin, M. Larval culture and rearing techniques of commercially important crab, Portunus pelagicus (Linnaeus, 1758): Present status and future prospects. Songklanakarin J. Sci. Technol. 2015, 37, 135-145. http://rdo.psu.ac.th/sjstweb/journal/37-2/37-2-4.pdf

23. Mann, D.; Paterson, B. Status of crab seed production and grow-out in Queensland. In Allan, G and Fielder, D. 2004. Mud crab aquaculture in Australia and Southest Asia. Proceedings of the ACIAR crab aquaculture scoping study and workshop, 28-29 April 2003, Bribie Island, Australia, 2004, pp.36-41.

24. Onn, K. K. Current practices in juvenile mud crab rearing. Aquaculture Asia Pacific 2013, 9(4), 44-46.

25. Quinito, E.T.; Parado-Estepa, F.D.; Rodriguez, E. Seed production of mud crab Scylla spp. Aquaculture Asia $2002,7(3), 29-31$.

26. Syafaat, M.N. Effect of water temperature on growth performance, moulting cycle, survival rate and sex ratio of mud crab, scylla paramamosain during nursery phase. M.Sc Thesis, Universiti Malaysia Terengganu. 2019.

27. Hassan, A.; Hai, T. N.; Chatterji, A.; Sukumaran, N. Preliminary study on the feeding regime of laboratory reared mud crab larva, Scylla serrata (Forsskal, 1775). World Appl. Sci. J. 2011, 14 (11), 1651-1654. 
28. Rodriguez, E.M.; Quinito, E.T.; Parado-Estepa, F.D.; Millamena, O.M. Culture of Scylla serrata megalops in brackishwater ponds. Asian Fish. Sci. 2001, 14, 185-189.

29. Ut, V. N.; Le Vay, L.; Nghia, T. T.; Hanh, T. T. H. Development of nursery culture techniques for the mud crab Scylla paramamosain (Estampador). Aquac. Res. 2007, 38, 1563-1568.

30. Ye, H.; Tao, Y.; Wang, G.; Lin, Q.; Chen, X.; Li, S. Experimental nursery culture of the mud crab Scylla paramamosain (Estampador) in China. Aquac. Int. 2011, 19, 313-321.

31. Ruscoe, I. M.; Shelley, C. C.; Williams, G. R. The combined effects of temperature and salinity on growth and survival of juvenile mud crabs (Scylla serrata Forskål). Aquaculture 2004, 238, 239-247.

32. Syafaat, M.N.; Gunarto.; Sulaeman.; Herlinah. Nursery of mud crab (Scylla olivacea Herbst, 1796) hatchery production seed in different containers. Proceeding of National Symposium of Marine and Fisheries, Hasanuddin University, 2017, pp. 808-816. In Indonesian

33. Gunarto.; Nurbaya.; Zakaria, M. Culture of Scylla olivacea Zoea 5 and Megalopa in different kind of tanks. Proceeding of Konferensi Akuakultur Indonesia, 2013, pp. 28-36. In Indonesian

34. Gunarto.; Parenrengi, A. Crablet of mangrove crab, Scylla olivacea rearing at the different salinity regimes. J. Aquac. Res. Dev. 2014., 5(5), 1000255.

35. Mirera, D. O.; Moksnes, P. O. Cannibalistic interactions of juvenile mud crabs Scylla serrata: the effect of shelter and crab size. Afr. J. Mar. Sci. 2013, 35(4), 545-553.

36. Gunarto. Effect of using the sea weed, Gracillaria sp in mud crab juvenile's nursery, Scylla olivacea in captivity. Proceeding of Seminar Nasional Perikanan Indonesia, 2012, 76-82. In Indonesian

37. Lee, D.O'C.; Wickins, J.F. Crustacean farming. New York: John Wiley \& Sons, Inc., 1992, 392 pp.

38. Macintosh, D.J.; Goncalves, F.; Soares, A.M.V.M.; Moser, S.M.; Paphavisit, N. Transport mechanisms of crab megalopae in mangrove ecosystems, with special reference to a mangrove estuary in Ranong, Thailand. In Keenan, C.P., Blackshaw, A., (Eds.), Mud Crab Aquaculture and Biology, ACIAR Proceeding, 1999, 178-186. https://www.aciar.gov.au/file/68781/download?token=Nhup $Y_{S} C Y$

39. Quinito, E.T.; Parado-Estepa, F.D.; Millamena, O.M.; Rodriguez, E.; Borlongan, E. Seed production of mud crab Scylla serrata juveniles. Asian Fish. Sci. 2001, 14, 161-174.

40. Genodepa, J.; Southgate, P. C.; Zeng, C. Diet particle size preference and optimal ration for mud crab, Scylla serrata, larvae fed microbound diets. Aquaculture 2004, 230, 493-505

41. Holme, M.H.; Zeng, C.; Southgate, P.C. Use of microbound diets for larval culture of the mud crab, Scylla serrata. Aquaculture 2006, 257, 482-490. https://doi.org/10.1016/j.aquaculture.2006.03.014

42. Holme, M.H.; Zeng, C.; Southgate, P.C. The effects of supplemental dietary cholesterol on growth, development and survival of mud crab, Scylla serrata, megalopa fed semi-purified diets. Aquaculture 2006, 261, 1328- 1334. https://doi.org/10.1016/j.aquaculture.2006.08.032

43. Holme, M.H.; Southgate, P.C.; Zeng, C. Assessment of dietary lecithin and cholesterol requirements of mud crab, Scylla serrata, megalopa using semi-purified microbound diets. Aquac. Nutr. 2007, 13, 413-423. https://doi.org/10.1111/j.1365-2095.2007.00492.x

44. Holme, M.H.; Southgate, P.C.; Zeng, C. Survival, development and growth response of mud crab, Scylla serrata, megalopae fed semi-purified diets containing various fish oil:corn oil ratios. Aquaculture 2007, 269, 427-435. https://doi.org/10.1016/j.aquaculture.2007.05.024

45. Ong, Q.M.; Fotedar, R.; Ho, T.T.H. Selection of locally available diets for rearing Scylla paramamosain megalopa to first crablet stage. Aquaculture 2020, 525, 735319. https://doi.org/10.1016/j.aquaculture.2020.735319

46. Antony, J.; Balasubramanian, C. P.; Balamurugan, C.; Sandeep, K. P.; Biju, I. F.; Vijayan, K.K. Optimisation of nursery rearing for megalopa of giant mud crab Scylla serrata (Forskal, 1775). Indian J. Fish. 2019, 66(1), 43-50.

47. Quinito, E.T.; Parado-Estepa, F.D. Transport of Scylla serrata megalopae at various densities and durations. Aquaculture 2000, 185, 63-71.

48. Heasman, M.P.; Fielder, D.R. Laboratory spawning and mass rearing of the mangrove crab, Scylla serrata (Forskal), from first zoea to first crab stage. Aquaculture 1983, 34, 303-316. https://doi.org/10.1016/0044-8486(83)90210-7

49. Usman.; Kamaruddin.; Laining, A. Substitution of Artemia nauplii with micro diet for mud crab, Scylla olivacea, larvae. Jurnal Riset Akuakultur 2018, 13(1), 29-38. In Indonesian. http://dx.doi.org/10.15578/jra.13.1.2018.29-38

50. Chen, X.; Lin, Q.; Wang, G.; Li, S.; Ye, H. Feeding in the megalopae of the mud crab (Scylla paramamosain) : mechanisms, plasticity, role of chelipeds and effect of prey density (abstract). Mar. Freshwater Behav. Physiol. 2013, 46, $321-336$. https://doi.org/10.1080/10236244.2013.833365

51. Serrano, Jr.A.E. Changes in gut evacuation time of larval mud crab, Scylla serrata (Crustacea : Portunidae) fed artificial plankton or live food. AACL Bioflux 2012, 5(4), 240-248. http://www.bioflux.com.ro/docs/2012.240-248.pdf

52. Serrano, Jr.A.E.; Traifalgar, R.F. Ontogeny and induction of digestive enzymes in Scylla serrata larvae fed live or artificial feeds or their combination. AACL Bioflux 2012, 5(3), 101-111. http://www.bioflux.com.ro/docs/2012.3.101-111.pdf

53. Gunarto.; Syafaat, M.N.; Herlinah.; Sulaeman.; Muliani. The effects of an artificial commercial feed supplementation on larval rearing and crablet production of mud crab Scylla tranquebarica. Indones. Aquac. J. 2018, 13(1), 13-21. http://dx.doi.org/10.15578/iaj.13.1.2018.13-21 
54. Permadi, S.; Juwana, S. Production of crab seedScylla paramamosain fed with Artemia nauplii and formulated diet containing spirulina and digezym. Oseanologi dan Limnologi di Indonesia 2015, 41(2), 181-189. In Indonesian. http://lipi.go.id/publikasi/produksi-benih-kepiting-scylla-paramamosain-dengan-ransum-nauplii-artemia-dan-digezym/1286

55. Quinito, E.T.; Estepa-Parado, F.; Alava, V. Development of hatchery techniques for the mud crab Scylla serrata (Forskal): Comparison of feeding schemes. In Keenan, C.P., Blackshaw, A., (Eds.), Mud Crab Aquaculture and Biology, ACIAR Proceeding, 1999, 125-130. https://repository.seafdec.org.ph/handle/10862/429

56. Taufik, M.; Bachok, Z.; Azra, M.N.; Ikhwanuddin, M. Effects of various microalgae on fatty acid composition and survival rate of the blue swimming crab Portunus pelagicus larvae. Indian J Mar Sci. 2016, 45(11), 1512-1521.

57. Hamasaki, K.; Suprayudi, M.A.; Takeuchi, T. Effects of dietary N-3HUFA on larval morphogenesis and metamorphosis to megalops in the seed production of the mud crab, Scylla serrata (Brachyura: Portunidae). Suisanzoshoku 2002, 50 (3), $333-340$. https://www.jstage.jst.go.jp/article/aquaculturesci1953/50/3/50 3 333/_pdf

58. Gunarto.; Herlinah. Level of crablet production in mangrove crab Scylla paramamosain with feeding enrichment using HUFA and vitamin C on larvae stages. Jurnal Ilmu dan Teknologi Kelautan Tropis 2015, 7(2), 511-520. http://medpet.journal.ipb.ac.id/index.php/jurnalikt/article/view/10997

59. Rodriguez, E.M.; Estepa, F.D.P.; Quinito, E.T. Extension of nursery culture of Scylla serrata (Forsskal) juveniles in net cages and ponds. Aquac. Res. 2007, 38, 1588-1592.

60. Ganesh, K.; Raj, Y.C.T.S.; Perumal, S.; Srinivasan, P.; Sethuramalingam, A. Breeding, larval rearing and farming of mangrove crab, Scylla serrata (Forskal, 1775). In Perumal, S., Thirunavukkarasu, A.R., Pachiappan, P., (Eds.), 2015. Advances in Marine and Brackishwater Aquaculture, Springer India, 2015, 163-172. https://doi.org/10.1007/978-81-322-2271-2 14

61. Shelley, C.; Lovatelli, A. Mud crab aquaculture - A practical manual. FAO, Fisheries and aquaculture technical paper No.567. Rome. 2011, 78 pp. http://www.fao.org/3/ba0110e/ba0110e00.htm

62. Nurdiani, R.; Zeng, C. Effects of temperature and salinity on the survival and development of mud crab, Scylla serrata (Forsakal) larvae. Aquac. Res. 2007, 38, 1529-1538.

63. Baylon, J. C. Effects of Salinity and Temperature on Survival and Development of Larvae and Juveniles of the Mud Crab, Scylla serrata (Crustacea: Decapoda: Portunidae). J. World Aquac. Soc. 2010, 41(6), 858-873.

64. Baylon, J. C. Survival and development of larvae and juveniles of the mud crab [Scylla olivacea Forskal (Crustacea: Decapoda: Portunidae)] at various temperatures and salinities. Philipp. Agric. Sci. 2011, 94(2), 195-204.

65. Baylon, J. C. The combined effects of salinity and temperature on the survival and development of zoea, megalopa and crab instar larvae of mud crab, Scylla tranquebarica (Fabricius 1798). Asian Fish. Sci. 2013, 26, 14-25.

66. Gong, J.; Yu, K.; Shu, L.; Ye, H.; Li, S.; Zeng, C. Evaluating the effects of temperature, salinity, starvation and autotomy on moulting success, moulting interval and expression of ecdysone receptor in early juvenile mud crabs, Scylla paramamosain. J Exp. Mar. Biol. Ecol. 2015, 464, 11-17.

67. Azra, M.N.; Ikhwanuddin, M.; Abol-Munafi, A.B. Behavioural data on instar crab movement at different thermal acclimation. Data Brief 2019, 22, 998-1002.

68. Wu, H.J.; Sun, L.B.; Li, C.B.; Li, Z.Z.; Zhang, Z.; Wen, X.B.; Hu, Z.; Zhang, Y.L.; Li, S.K. Enhancement of the immune response and protection against Vibrio parahaemolyticus by indigenous probiotic Bacillus strains in mud crab (Scylla paramamosain). Fish Shellfish Immun. 2014, 41, 156-162.

69. Yamin, M.; Sulaeman. Transportation of mud crab crablet (Scylla paramamosain) with dry system. Proceeding of Forum Inovasi Teknologi Akuakultur 2011, pp. 1297-1302. In Indonesian.

70. Sulaeman.; Yamin, M.; Parenrengi, A. Transport of mud crab (Scylla paramamosain) crablets at different packing densities. Jurnal Riset Akuakultur 2008, 3(1), 99-104.

71. Heasman, M. P. Aspect of the general biology and fishery of the mud crab Scylla serrata (Forskal) in Moreton Bay, Queensland. Ph.D Thesis, University Of Queensland, 1980.

72. Venugopal, G.; Rasvi, S.S.H.; Babu, S.P.P.; Reddy, P.R.; Mohan, K.M.; Rao, P.S.; Patnaik, R.R. Performance evaluation of mud crab Scylla serrata (Forskal, 1775) in monoculture, monosex culture and polyculture. J. Mar. Biol. Assoc. 2012, 54 (2), 5-8. 